\title{
Termal Turizmin Bölgesel Kalkınmaya Etkisi: Eskişehir Uygulaması
}

\section{The Effect of Thermal Tourism on Regional Development: Eskişehir Application}

\author{
Doç.Dr. İnci PARLAKTUNA \\ Eskişehir Osmangazi Üniversitesi \\ İktisadi ve İdari Bilimler Fakültesi \\ E-posta: incip@ogu.edu.tr
}

\author{
Elis DiNÇER \\ Eskişehir Osmangazi Üniversitesi \\ Sosyal Bilimler Enstitüsü \\ E-posta: elisdincer@hotmail.com.tr
}

Öz

Bölgesel kalkınma sahip olunan doğal kaynaklara bağlı olduğu kadar bu kaynakların etkin ve verimli kullanımıyla da yakın ilişkilidir. Bu çalışma, "Termal Turizm Master Planı" kapsamında yer alan Eskişehir'deki doğal kaynakların termal turizm amaçlı olarak kullanımını ve kalkınma ile ilişkisini değerlendirmeyi amaçlamaktadır. Çalışmada üç bölümden oluşan soru formu hazırlanmış ve Eskişehir'de bulunan tesis yöneticileri ile yüz yüze görüşme yapılarak uygulanmıştır. Eskişehir termal kaynaklarının etkin kullanılmadığı, atıl kaldığı, Termal Turizm Master Planı'nın bölge için hayata geçirilemediği ve kalkınmasında termal kaynakların yeterli düzeyde kullanılmadığı sonucuna ulaşılmıştır.

Anahtar Kelimeler: Doğal Kaynaklar, Termal Turizm, Bölgesel Kalkınma, Eskişehir, Turizm Politikaları.

\begin{abstract}
Regional development depends on natural resources. It is also important to use these resources effectively and efficiently. This study aims to use the natural resources of Eskişehir in "The Thermal Tourism Master Plan" for thermal tourism purposes and their relationship with development. In the study, a three-part questionnaire was prepared and applied to face-to-face interviews with facility managers in Eskişehir. It has been concluded that Eskişehir thermal resources are not used effectively and remain idle and Thermal Tourism Master Plan cannot be implemented for the region and also thermal resources are not used sufficiently in development.
\end{abstract}

Key Words: Natural Resource, Thermal Tourism, Regional Development, Eskişehir, Tourism Policies.

\footnotetext{
* Bu çalışma Doç. Dr. Inci PARLAKTUNA'nın danışmanlığında Eskişehir Osmangazi Üniversitesi Sosyal Bilimler Enstitüsü Iktisat Anabilim Dalında hazırlanan, Elis DiNÇER'in "Bölgesel Kalkınmada Termal Turizm: Eskişehir İline Yönelik Bir Inceleme” (2018) başlıklı Yüksek Lisans Tez’inden üretilmiştir
} 


\section{Giriş}

Toplumların iktisadi ve sosyo-kültürel yapısının olumlu yönde değişimi ve gelişimi olarak ifade edilen kalkınma sürecinde doğal kaynakların rasyonel kullanımı oldukça önemlidir (Çeken, 2008: 294-297; Başol ve diğ., 2005: 67). Doğal kaynaklar her ülke ya da bölgeye özgü olacak biçimde çeşitlilik göstermektedir. Ancak gelişmekte olan pek çok ülke araştırma ve geliştirme çalışmalarının eksikliği nedeniyle doğal kaynakların varlığı, mevcut potansiyeli, niteliği ve kullanım alanlarıyla ilgili yeterli bilgiye sahip değildir. Bu ülkelerin kalkınmalarında üretim faktörleri arasında yer alan doğal kaynakların etkin bir şekilde kullanımı önemli rol oynamaktadır. Öncelikle ülkelerin mevcut doğal kaynaklarının durum analizi yapılarak bir envanterin çıkarılması anlamlıdır. Sonrasında ise ülke ya da bölgenin diğer dinamik özellikleri dikkate alınarak bölgenin doğal kaynakları düzenlenebilir ve stratejik önceliğe sahip sektörlere entegre edilebilir (Başol, 1994: 28; Kaya, 2009: 218-221). Böylece doğal kaynaklar açısından zengin olan ülkeler pek çok kanalla gelir elde edebilirler. Bu kanallardan biri de turizm sektörüdür (Çeken, 2016: 115-120). Bunun yanı sıra turizm otomasyona oldukça uzak, emek-yoğun bir sektör olduğundan bu alanda yapılan yatırımlar yeni iş alanları yaratmaktadır. Bu durum beşeri sermayeye olan talebi arttırmakta ve istihdam artışı sağlamaktadır. Turizmin pek çok sektörle doğrudan ya da dolaylı olarak etkileşimde olması istihdam artışını sürekli kılmaktadır. Birleşmiş Milletler Dünya Turizm Örgütü'nün 2017 yılında yayınladığı rapora göre, dünya genelinde her 10 kişiden 1'i turizm sektörü ile ilişkili bir alanda istihdam edilmektedir. İstihdam yaratma kapasitesinin önemli belirleyicileri arasında ülkelerin ekonomik yapıları, istihdam politikaları, nitelikli personel ve turizm çeşitliliği gibi faktörler sıralanabilir (Çeken, 2016: 139; UNWTO, 2017: 3). Turizm sektörünün yüksek gelir ve istihdam kapasitesinden faydalanmak isteyen ülkeler turizm faaliyetlerini bütün bir yıla yayma çabasıyla alternatif turizm türlerine yönelmektedirler. Bu alternatif turizm türlerinden biri termal turizmdir. Doğal kaynaklara dayanan termal turizm sağlık turizmi alt başlığında yer almaktadır.

Termal turizm açısından Almanya Avrupa ülkeleri arasında en cazip olan ülkedir. Almanya, Avrupa termal turizm pazarının yaklaşık \%50' sini oluşturmaktadır. Bu pazarda 291 adet resmi belgeli termal tesis bulunmakta ve yaklaşık 280 bin kişi istihdam edilmektedir. Termal tesislerin yatak kapasitesi 900.000 civarındadır. Ülke yılda yaklaşık 12 milyon turist tarafından ziyaret edilmektedir. Çağdaş termal turizmin gelişimini hızlandırmak için konusunda uzman personeller yetiştirmek amacıyla 26 tıp fakültesinde balneoloji eğitimi verilmektedir. Bad Füssing, Bad Griesbach, Baden Baden ve Wiesbaden Almanya'nın en önemli kaplıca kentleridir (Aksu ve Aktuğ, 2011: 6; Özbek, 2015: 73). İtalya bu pazarda Almanya'dan sonra turist çeken ikinci ülkedir. Termal turizm İtalya için önemli bir gelir kaynağıdır. İtalya'da 360'a yakın termal tesis yııın on iki ayında aktiftir. Teknoloji ve tıbbi uygulamalar açısından oldukça ileri düzeyde olan Fransa ise 100'den fazla termal tesise sahiptir. Son yıllarda gelişen Çek Cumhuriyeti ve Slovakya'daki termal tesisler yılda 500.000'e yakın hastaya tedavi hizmeti vermektedir (Aksu ve Aktuğ, 2011: 7; Özdipçiner, 2018: 31-32; Tengilimoğlu ve Karakoç, 2013: 87-88; Yardan ve diğ., 2014: 36). Ülkeler sahip oldukları termal kaynaklar açısından değerlendirildiğinde Türkiye, Avrupa ülkeleri arasında birinci sırada, dünya ülkeleri arasında da yedinci sırada yer almaktadır. Bu termal kaynaklar termal turizmde elverişli bir şekilde değerlendirilebilecek niteliktedir (Özbek, 2015: 57).

Türkiye gerek tarihi gerek coğrafi özellikleri ile eşsiz bir termal turizm merkezi olmasına rağmen, uluslararası standartlarda hizmet verebilecek yeterli düzeyde termal turizm tesisi mevcut değildir. Bu yetersizlik sağlık turizm ile ilişkili alternatif turizm türlerinin gelişmesini engellemekte ve gelir kayıplarına neden olmaktadır (Tontuş, 05. 
03.2017). "Türkiye Turizm Stratejisi 2023” kapsamında Kültür ve Turizm Bakanlığı'nca (2007) söz konusu gelir kayıplarını engellemek amacıyla "Termal Turizm Master Planı" hazırlanmıştır (Kültür ve Turizm Bakanlığı, 07.05.2018; Özdipçiner, 2018: 41). Bu çalışma, "Termal Turizm Master Planı" kapsamında yer alan Eskişehir'deki doğal kaynakların termal turizm amaçlı olarak kullanımını ve bölgesel kalkınma ilişkisini değerlendirmeyi amaçlamaktadır.

Bu çalışmanın birinci bölümde doğal kaynakların kalkınma ilişkisi ve dünyadaki termal turizm destinasyonları anlatılmıştır. İkinci bölümde termal turizmin bölgesel kalkınma üzerindeki etkileri, Türkiye'deki termal kaynak potansiyeli ve termal turizm politikalarından bahsedilmektedir. Üçüncü bölümde Eskişehir uygulamasına yönelik metodoloji anlatılmış dördünce bölümde ise elde edilen bulgular açıklanmış ve değerlendirilmiştir. Beşinci bölümde sonuç ve önerilere yer verilmiştir.

\section{Bölgesel Kalkınmada Termal Turizm}

Bölgesel kalkınma, bir bölge ya da yörenin mevcut doğal kaynaklarına, kaynakların verimli kullanımına, iktisadi ve sosyo-kültürel yapısının olumlu yönde değişimine, gelişimine ve bu sayede gerçekleşecek olan refah seviyesindeki artışa bağlıdır. Doğal kaynak açısından her bölge farklı dinamiklere sahiptir. İhracı mümkün olmayan kaynaklar açısından zengin olan bölgeler kaynaklarını turistik çekim unsuru olarak etkin şekilde kullanarak turizm gelirine dönüştürebilirler (Çeken, 2016: 115-120). Bu bağlamda termal kaynakların termal turizm alanında rasyonel kullanımı oldukça önemlidir. Termal turizm; termomineral sular kullanılarak, balneoterapi ${ }^{1}$, içme ve inhalasyon (soluma) gibi çeşitli uygulama alanına sahip yöntemlerin yanında iklim kürü, fizik tedavi, rehabilitasyon, egzersiz, psikoterapi, diyet gibi destek tedavi yöntemlerinin koordineli bir biçimde bütünleştirilmesi ile ortaya çıkan kür (tedavi) uygulamalarının yanı sıra termal suların rekreasyon amaçlı olarak kullanılmasıdır (Kültür ve Turizm Bakanlığı, 02.05.2017). Bu bağlamda tıbbi tedavi niteliği olan termal kaynak potansiyeline sahip bölgeler doğal kaynaklarını turistik çekim alanlarına dönüştürerek termal turizm alanında değerlendirebilmekte ve ihracı mümkün olmayan doğal kaynaklarından döviz getirisi sağlayabilmektedir (Çeken, 2016: 118). Termal suların termal turizm anlayışı ile kullanımı termal kompleksler sayesinde gerçekleştirilebilmektedir. Termal kompleks, yılın her mevsiminde 7-21 gün süreyle tedavi, konaklama ve her türlü intiyacın karşılanabileceği uygun alt ve üst yapıya sahip olup diğer turizm otellerinden oldukça farklı bir yapı içermektedir (Özbek, 2015:64). Termal turizmin bölgesel kalkınmaya etkisi aşağıdaki gibi sıralanabilir (Çeken, 2016: 119-120; Özbek, 2015: 64; Tontuş, 20.12.2016; Tontuş, 05.03.2017):

- Sağlığı geliştirmeye, korumaya ve tedavi etmeye yönelik olan termal kür uygulamaları 7-21 gün aralığında hekimlerin tavsiye edeceği şekilde gerçekleştirilen uygulamalar olduğundan gerek tedavi süresi gerekse uygulamaların bağlılık ve tekrar gerektirmesi gibi temel belirleyiciler termal tesislerin yıl boyu doluluk oranlarının yüksek kalmasını sağlamaktadır. Bu durum sürekli gelir kazanımını beraberinde getirmektedir.

- Termal kür süresinin uzunluğu gereği ziyaretçiler ve refakatçiler için rekreasyon alanları yaratılarak bölge bir destinasyon merkezi olarak

\footnotetext{
${ }^{1}$ Balneoterapi: termal ya da mineralli suların, peloidlerin (çamurların) ve gazların, yöntem ve dozları belirlenmiş, banyo, paket, içme ve inhalasyon uygulamaları şeklinde, düzenli aralıklarla ve seri halde tekrarlanarak kullanılmasıyla, belirli bir zaman aralığında ve kür tarzında gerçekleştirilen bir uyarı-uyum tedavisidir (Karagülle, 05.05.2017).
} 
planlandığı takdirde turistik ürün çeşitliliğine bağlı olarak ziyaretçilerin artan harcamaları doğrultusunda bölgenin geliri artmaktadır. Bu durum turizm sektörüyle etkileşim halinde olan diğer sektörlerin gelirini de olumlu etkilemektedir.

- Insan sağlığını merkeze alması sebebiyle çok özel bir alan olan termal turizm, sunduğu hizmet seçeneklerinin genişliği paralelinde süreklilik içeren istihdam alanları yaratmaktadır. Ancak, gerek termal tedavi ve termal tedaviye destek nitelikte olan uygulamalar için sağlık personelleri ve yardımcı personellerin gerekse her türlü tesis hizmet ve aktivitelerinde yer alacak olan personellerin kalifiye olmaları vazgeçilmez koşuldur. Bunun yanı sıra termal kaynağın ait olduğu bölgenin sosyo-kültürel özellikleri bir turistik çekim unsuru olarak ziyaretçilere sunulabilmekte ve bu sayede o bölgede yaşayanlara da yeni istihdam alanları sağlanmaktadır.

Tedavi olmak ve sağlığını koruyup geliştirmek amacıyla termal tesislere giden ziyaretçiler kür uygulamaları, destek tedavi uygulamaları ve bölgenin özelliklerine göre geliştirilebilecek diğer turistik ürünlerden bütüncül olarak yararlanmaktadırlar. Bütüncül yaklaşım tesislerde yıl boyu doluluk oranlarının yüksek kalmasını, istihdam ve gelirin sürekliliğini sağlamakta olup bu sayede bölgeler arası dengesizlikleri giderebilmektedir. Bu durum ekonomik kalkınmanın temel dinamiği olan yatırımların gerçekleştirilebilmesi için büyük önem arz etmektedir.

Türkiye jeotermal kaynak potansiyeli bakımından Avrupa ülkeleri arasında birinci, Dünya ülkeleri arasında ise yedinci ülke konumundadır. Sayıları 1500'ün üzerinde olan termal kaynakların sıcaklıkları $20-110^{\circ} \mathrm{C}$ arasında, debileri ise $2-500$ litre/saniye arasında değişmektedir. Kükürt, radon ve tuz bakımından oldukça zengin olan kaynakların termal tedavi için kişi başına termal su arzı 350 litre/gün olup bu durum bir günde yaklaşık bir milyon kişinin yararlanabileceği kadar termal potansiyelin varlığına işaret etmektedir (Özbek, 1990; Özbek, 2015: 57; Özdemir, 2015: 7; Şimşek, 2003: 31). Bunun yanı sıra iklim özellikleri gereği yıllık termal tedavi süresi pek çok Avrupa ülkesini geride bırakarak 220-240 güne kadar uzayabilmektedir (Tontuş, 05.03.2017). Bu durum bölgesel kalkınma süreci için oldukça anlamlıdır. Global Wellness Institute (2017) raporuna göre; 2015 yılı itibariyle küresel anlamda termal turizm ekonomisi yaklaşık 51 milyar dolardır (Yeung ve Johnston, 2017: 5). Termal turizmden en çok gelir elde eden ilk 10 ülke ise sırasıyla Tablo 1'de yer almakta olup Türkiye 691,5 milyon dolar ile 7. sıradadır.

Tablo 1: Termal Turizmden En Çok Gelir Elde Eden Ülkeler (Milyar Dolar)

\begin{tabular}{|l|c|}
\hline Ülkeler & Termal Turizm Geliri (2015) (Milyar Dolar) \\
\hline Çin & $15,721,6$ \\
\hline Japonya & $12,493,4$ \\
\hline Almanya & $6,823,7$ \\
\hline Rusya & $3,075,9$ \\
\hline İtalya & $1,674,5$ \\
\hline Avusturya & 905,1 \\
\hline Türkiye & 691,5 \\
\hline Macaristan & 665,9 \\
\hline İspanya & 658,8 \\
\hline Polonya & 620,6 \\
\hline
\end{tabular}

Kaynak: Yeung ve Johnston, 2017: 29. 
Türkiye'nin termal turizm açısından tarihi ve coğrafi üstünlükleri yakın geçmişe kadar uluslararası pazarda yeterince değerlendirilememiştir. Bu bağlamda "Termal Kent" niteliğinde destinasyonlar yaratabilmek için "Termal Turizm Kentleri Projesi" hazırlanmıştır. Şekil 1'de proje kapsamına alınan bölgeler yer almaktadır.

\section{Şekil 1: Termal Turizm Kentleri Bölgeleri Haritası}

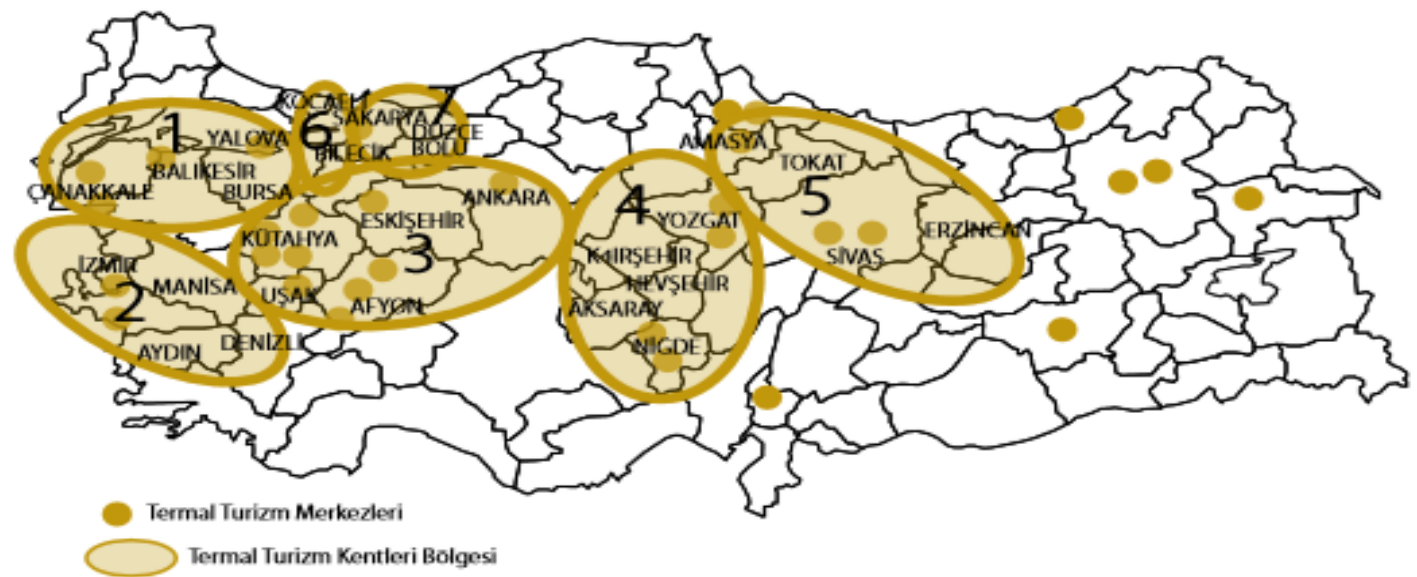

Kaynak: Aydın, 2014: 149.

Güney Marmara Termal Turizm Kentleri Bölgesi: Balıkesir, Çanakkale, Yalova

Güney Ege Termal Turizm Kentleri Bölgesi: Aydın, Denizli, Manisa, İzmir

Frigya Termal Turizm Kentleri Bölgesi: Afyonkarahisar, Ankara, Uşak, Eskişehir, Kütahya

Orta Anadolu Termal Turizm Kentleri Bölgesi: Aksaray, Kırşehir, Niğde, Nevşehir, Yozgat

Kuzey Anadolu Termal Turizm Kentleri Bölgesi: Amasya, Sivas, Tokat, Erzincan

Doğu Marmara Termal Turizm Kentleri Bölgesi: Bilecik, Kocaeli

Batı Karadeniz Termal Turizm Kentleri Bölgesi: Bolu, Düzce Sakarya

"Termal Turizm Kentleri Bölgeleri" turistik çekim merkezi olmak üzere planlanırken termal kaynak potansiyelinin yanı sıra ulusal ve uluslararası öneme sahip kültürel değerler, ulaşım imkânları, doğal güzellikler, iklim koşulları ve diğer alternatif turizm türleri ile bütünleşebilme olanakları dikkate alınmıştır. Bu sayede termal bölgelerde doğal kaynakların etkin kullanımı sağlanarak hem iktisadi hem de sosyokültürel yapının olumlu yönde değişimi, gelişimi ve nihayetinde de refah seviyesinde artış yaşanması hedeflenmektedir (Aydın, 2014: 150; Çeken, 2008: 294-297). Refah seviyesinin göstergesi ise Birleşmiş Milletler İnsani Kalkınma Programı (UNDP) tarafından geliştirilen, gelir bileşeninin yanı sıra sağlık ve eğitim bileşenlerini de kapsayan ve her yıl ülkelere göre hesaplanan İnsani Gelişme Endeksi (IGE)'dir. 2010 yılı itibariyle düzenleme yapılan endeks hesaplamasında; gelir bileşeninin göstergesi olarak kişi başına gayri safi yurt içi gelir değişkeni, sağlık bileşeninin göstergesi olarak beklenen yaşam süresi değişkeni, eğitim bileşeninin göstergesi olarak ise ortalama okullaşma yılı ve beklenen okullaşma yılı değişkenleri kullanılmaktadır. Endeks her yıl ülkeler için hesaplanmakta olup bazı ülkelerde iller ve eyaletler için de hesaplanmaktadır. Ancak Türkiye'de iller için resmi kurumlar tarafından hesaplama yapılmamaktadır (Gülel ve diğ., 2017: 208-210). Gülel ve diğ. (2017) çalışmasında Türkiye'de 2013 yılı için illere göre IGE'ni hesaplamıştır. Bu bağlamda söz konusu çalışma bulgularından yararlanılarak “Termal Kent”ler için eğitim-sağlık-gelir alt endeksleri ile birlikte IGG'nin yer aldığı ve Türkiye sıralamalarının bulunduğu Tablo 2 hazırlanmıştır. Eğitim alt endeksi bakımından termal kentler değerlendirildiğinde Frigya Termal Turizm Bölgesi'nde yer alan Eskişehir 1. sırada ve Ankara 2. sırada, Doğu Marmara Termal Turizm Bölgesi'nde Bilecik 3. sıradadır. Sağlık alt endeksi bakımından termal kentler değerlendirildiğinde hiçbir termal kent ilk 3 sırada yer 
almamaktadır. Gelir alt endeksi bakımından termal kentler değerlendirildiğinde Doğu Marmara Termal Turizm Bölgesi'nde yer alan Kocaeli 1. sırada, Frigya Termal Turizm Bölgesi'nde yer alan Ankara 3. sıradadır. IGE bakımından termal kentler değerlendirildiğinde ise Frigya Termal Turizm Bölgesi'nde yer alan Ankara 1. sırada, Güney Ege Termal Turizm Bölgesi'nde yer alan İzmir 2. sırada ve Doğu Marmara Termal Turizm Bölgesi'nde yer alan Kocaeli 3. sırada yer almaktadır.

Söz konusu bölgelerde refah düzeyinin olumlu etkilenerek bölgeler arası dengesizliklerin giderilmesine destek olmak amacıyla termal kaynakların termal turizme çağdaş termal turizm kompleksleri aracılığıyla entegre edilmesini sağlamak üzere kısa dönemde (2007-2012) 50.000, orta dönemde (2012-2017) 100.000, uzun dönemde (2017-2023) 500.000 yatak kapasitesi hedeflenmiştir. Bu sayede Türkiye'nin termal turizm bağlamında Avrupa'da birinci destinasyon ülke konumuna erişebileceği ve termal turist sayısının 15 milyona ulaşacağı öngörülmektedir (Aydın, 2014: 150-151).

Tablo 2: Termal Kentlerin Alt Endeksleri ve İnsani Gelişme Endeksi

\begin{tabular}{|c|c|c|c|c|c|c|c|c|}
\hline \multirow{2}{*}{$\begin{array}{l}\text { Termal Turizm } \\
\text { Bölgelerine göre } \\
\text { Kentler }\end{array}$} & \multicolumn{2}{|c|}{ Eğitim Alt Endeksi } & \multicolumn{2}{|c|}{ Sağlık Alt Endeksi } & \multicolumn{2}{|c|}{ Gelir Alt Endeksi } & \multicolumn{2}{|l|}{$\overline{\text { İGE }}$} \\
\hline & Endeks & $\begin{array}{c}\text { Türkiye } \\
\text { sıralaması }\end{array}$ & Endeks & $\begin{array}{c}\text { Türkiye } \\
\text { siralaması }\end{array}$ & Endeks & $\begin{array}{c}\text { Türkiye } \\
\text { Siralaması }\end{array}$ & İGE & $\begin{array}{c}\text { Türkiye } \\
\text { sıralaması }\end{array}$ \\
\hline \multicolumn{9}{|l|}{$\begin{array}{l}\text { Güney } \\
\text { Marmara }\end{array}$} \\
\hline Balıkesir & 0,815 & 21 & 0,487 & 51 & 0,343 & 28 & 0,514 & 29 \\
\hline Çanakkale & 0,875 & 9 & 0,472 & 56 & 0,356 & 25 & 0,528 & 27 \\
\hline Yalova & 0,840 & 15 & 0,778 & 10 & 0,422 & 14 & 0,651 & 7 \\
\hline \multicolumn{9}{|l|}{ Güney Ege } \\
\hline Aydın & 0,763 & 31 & 0,648 & 25 & 0,320 & 33 & 0,541 & 24 \\
\hline Denizli & 0,785 & 25 & 0,673 & 20 & 0,418 & 15 & 0,604 & 12 \\
\hline Manisa & 0,719 & 43 & 0,484 & 53 & 0,350 & 26 & 0,496 & 39 \\
\hline İzmir & 0,851 & 14 & 0,694 & 18 & 0,773 & 4 & 0,770 & 2 \\
\hline \multicolumn{9}{|l|}{ Frigya } \\
\hline Afyonkarahisar & 0,648 & 51 & 0,383 & 70 & 0,250 & 46 & 0,396 & 58 \\
\hline Ankara & 0,942 & 2 & 0,741 & 13 & 0,780 & 3 & 0,817 & 1 \\
\hline Uşak & 0,783 & 27 & 0,505 & 50 & 0,305 & 36 & 0,494 & 40 \\
\hline Eskişehir & 0,948 & 1 & 0,456 & 59 & 0,428 & 13 & 0,570 & 18 \\
\hline Kütahya & 0,827 & 18 & 0,321 & 76 & 0,298 & 39 & 0,430 & 53 \\
\hline \multicolumn{9}{|l|}{ Orta Anadolu } \\
\hline Aksaray & 0,515 & 64 & 0,639 & 26 & 0,339 & 31 & 0,482 & 44 \\
\hline Kırşehir & 0,826 & 19 & 0,609 & 29 & 0,265 & 42 & 0,511 & 33 \\
\hline Niğde & 0,648 & 52 & 0,575 & 36 & 0,172 & 61 & 0,400 & 57 \\
\hline Nevşehir & 0,726 & 41 & 0,405 & 67 & 0,263 & 43 & 0,426 & 55 \\
\hline Yozgat & 0,544 & 61 & 0,519 & 48 & 0,174 & 59 & 0,366 & 62 \\
\hline \multicolumn{9}{|l|}{ Kuzey Anadolu } \\
\hline Amasya & 0,857 & 12 & 0,519 & 49 & 0,262 & 44 & 0,488 & 42 \\
\hline Sivas & 0,685 & 46 & 0,445 & 62 & 0,295 & 40 & 0,448 & 49 \\
\hline Tokat & 0,552 & 60 & 0,447 & 61 & 0,167 & 63 & 0,345 & 63 \\
\hline Erzincan & 0,752 & 33 & 0,742 & 12 & 0,226 & 53 & 0,501 & 36 \\
\hline
\end{tabular}


Tablo 2'nin devamı

\begin{tabular}{|l|c|c|c|c|c|c|c|c|}
\hline Doğu Marmara & & & & & & & & \\
\hline Bilecik & 0,921 & 3 & 0,468 & 58 & 0,305 & 37 & 0,508 & 34 \\
\hline Kocaeli & 0,838 & 16 & 0,486 & 52 & 1,000 & 1 & 0,741 & 3 \\
\hline Batı Karadeniz & & & & & & & & \\
\hline Bolu & 0,893 & 7 & 0,726 & 15 & 0,371 & 21 & 0,622 & 11 \\
\hline Düzce & 0,727 & 40 & 0,541 & 42 & 0,342 & 29 & 0,512 & 30 \\
\hline Sakarya & 0,757 & 32 & 0,429 & 65 & 0,389 & 17 & 0,502 & 35 \\
\hline
\end{tabular}

Kaynak: Gülel ve diğ., 2017: 212-214.

Ek 1'den gelişimi izlenebileceği gibi "Termal Turizm Kentleri Projesi" nin kısa dönemi olan 2007-2012 yılları arasında, Turizm Yatırım Belgeli (TYB) ve Turizm İşletme Belgeli (TiB) olmak üzere turizm belgeli termal tesislerin sayısı 22'den 77'ye yükselmiştir. Tesislerin yatak sayısı ise 9194'ten 27210'a ulaşmıştır. Projenin orta dönemi olan 2012-2017 yılları arasında ise turizm belgeli termal tesislerin sayısı toplamda 117'ye yükselmiş olup yatak sayısı 46184'e ulaşmıştır (Kültür ve Turizm Bakanlığı, 25.02.2018). Bu bağlamda orta dönemin sonunda turizm belgeli termal tesis kapasitesi başlangıç döneminden itibaren yaklaşık olarak 5 katına çıkmıştır. Ancak, orta dönem hedefi olan 100.000 yatak kapasitesine turizm belgeli tesisler itibariyle ulaşılamamıştır. Öte yandan Türkiye'de 2016 yılı itibariyle 40 ilde Sağlık Bakanlığı tarafından izin verilmiş 246 adet kaplıca tesisi bulunmaktadır (Sağlık Bakanlığı, 20.07.2017). Söz konusu dönemde Türkiye'deki termal turizm işletme belgeli tesislere yerli ve yabancı termal turistlerin geliş sayıları, ortalama kalış süreleri ve tesislerin doluluk oranları Tablo 3'de yer almakta olup yıllar itibariyle yerli termal turist geliş sayısında artış yaşanmakla birlikte aynı oranda bir artış yabancı termal turist geliş sayısı bakımından izlenememektedir. Türkiye bu bağlamda önde gelen Avrupa ülkelerinin çok gerisinde kalmaktadır. Örneğin; bir yılda sadece Almanya'nın Bad Fussing termal tesislerinin ziyaretçi sayısı yaklaşık olarak Türkiye'nin tüm termal tesislerinde ki ziyaretçi sayısına eşittir (Tontuş, 05.03.2017). Yerli ve yabancı termal turistlerin ortalama kalış süreleri termal tedavi için son derece yetersiz olmakla birlikte termal tesislerin toplam doluluk oranı da yaklaşık \%40 civarında sağlanabilmektedir.

Tablo 3: Yıllar İtibariyle Turizm İşletme Belgeli Termal Otellere Yerli ve Yabancı Ziyaretçilerin Geliş Sayısı, Ortalama Kalış Süreleri ve Doluluk Oranı (\%)

\begin{tabular}{|l|c|c|c|c|c|c|}
\hline \multirow{2}{*}{ Yıllar } & \multicolumn{2}{|c|}{$\begin{array}{c}\text { Termal Otellere Geliş } \\
\text { Sayısı }\end{array}$} & \multicolumn{2}{c|}{$\begin{array}{c}\text { Ortalama Kalış } \\
\text { Süresi }\end{array}$} & \multicolumn{2}{c|}{ Doluluk Oranı (\%) } \\
\cline { 2 - 7 } & $\begin{array}{c}\text { Yerli } \\
\text { Ziyaretçi }\end{array}$ & $\begin{array}{c}\text { Yabancı } \\
\text { Ziyaretçi }\end{array}$ & $\begin{array}{c}\text { Yerli Ziyaretçi } \\
\text { Yabancı }\end{array}$ & $\begin{array}{c}\text { Yerli } \\
\text { Ziyaretçi }\end{array}$ & $\begin{array}{c}\text { Yabancı } \\
\text { Ziyaretçi }\end{array}$ & Ziyaretçi \\
\hline $\mathbf{2 0 1 0}$ & 457909 & 302725 & 2.1 & 1.3 & 25.98 & 10.87 \\
\hline $\mathbf{2 0 1 1}$ & 636363 & 450904 & 2.1 & 1.3 & 30.42 & 13.46 \\
\hline $\mathbf{2 0 1 2}$ & 789472 & 451399 & 2.1 & 1.5 & 30.91 & 12.36 \\
\hline $\mathbf{2 0 1 3}$ & 901820 & 477242 & 2.0 & 1.4 & 31.01 & 11.64 \\
\hline $\mathbf{2 0 1 4}$ & 1006252 & 552052 & 2.0 & 1.5 & 30.27 & 12.39 \\
\hline $\mathbf{2 0 1 5}$ & 1132555 & 534670 & 1.9 & 1.5 & 30.77 & 11.11 \\
\hline $\mathbf{2 0 1 6}$ & 1134851 & 203621 & 2.0 & 1.8 & 29.15 & 4.69 \\
\hline
\end{tabular}

Kaynak: Kültür ve Turizm Bakanlığı, 01.03.2018.

Termal turizmin bölgesel kalkınma sürecine destek olabilmesi ziyaretçilerin geliş sayısı, ortalama kalış süreleri ve nihayetinde termal tesislerin toplam doluluk oranıyla yakın ilişkilidir. Bölgesel kalkınma, ziyaretçilerin sağlık ve turizm olanaklarından 
bütüncül olarak yararlanabileceği; standart konaklama tesisinin yanı sıra kür merkezi ve rekreasyon alanlarını da kapsayan uygun alt ve üst yapıya sahip ve nihayetinde uluslararası standartlarda hizmet verebilen kompleks yapıda termal tesislerin varlığı ile gerçekleşebilecektir (Özbek, 2015: 64; Tokmak, 2015: 64-67).

Türkiye'nin genelinde olduğu gibi termal turizm adına oldukça elverişli termal kaynaklara ev sahipliği yapan illerden biri de Eskişehir'dir. Eskişehir'de yer alan Günyüzü Hamamkarahisar (Çardak) Kaplıcası Türkiye'nin birinci derecede, Hasırca Kaplıcası ve Mihalgazi- Sakarılıca Kaplıcası üçüncü derecede önem ve öncelikli termal kaynaklar arasındadır (Banger, 2002: 54-65). Ayrıca 08.12.2006 tarih ve 26370 sayılı Resmi Gazete' de yayımlanarak yürürlüğe giren, 20.11.2006 tarih ve 11264 sayılı Bakanlar Kurulu Kararı ile Eskişehir il merkezine 13 km uzaklıkta yer alan Kızılinler bölgesi "Termal Turizm Merkezi” ilan edilmiştir (Eskişehir Turizm Master Planı 20112015, 2011: 10; Eskişehir İI Kültür ve Turizm Müdürlüğü, 11.03.2018). Ayrıca Eskişehir il merkezine 32 km uzaklıkta yer alan Mihalgazi- Sakarılıca Bölgesi 17.10.1993 tarihli 21731 sayılı Resmi Gazete ile "Sarıcakaya Termal Turizm Merkezi" ilan edilmiş olup 2006 yılında sınırları genişletilmiştir (Banger, 2002: 65-68; Eskişehir İı Kültür ve Turizm Müdürlüğü, 09.03.2018). Kızılinler ve Mihalgazi-Sakarılıca kaplıcaları "Termal Turizm Merkezi" ilan edilmiş olmasına rağmen, uluslararası boyutlarda termal turizm alanında değerlendirilemeyen bölgelerdir (Eskişehir Turizm Master Planı 2011-2015, 2011: 10). Araştırma döneminde Kızılinler ve Mihalgazi-Sakarılıca Bölgeleri ziyaret edilmiş ve Termal Turizm Master Planı'nın hayata geçirilemediği izlenmiştir. Bu nedenle çalışma Eskişehir'in şehir merkezinde faaliyet gösteren tesislerde yapılmıştır.

\section{Eskişehir Uygulaması}

Bu çalışma, “Termal Turizm Master Planı” kapsamında yer alan Eskişehir'deki doğal kaynakların termal turizm amaçlı olarak kullanımı ve bölgenin kalkınma ile ilişkisinin değerlendirilmesi amaçlanmaktadır. Bu bağlamda çalışma kapsamına Eskişehir'de Turizm İşletme Belgesi'ne sahip olan ve bunun yanı sıra Sağlık Bakanlığı tarafından "Kaplıca Tesisi İşletme İzni” verilmiş dört adet tesis ele alınmıştır. Çalışma kapsamına alınan tesislere A, B, C ve D tesisi olmak üzere temsili isimler verilmiştir. Eskişehir'de mevcut kaynakların termal turizm amaçlı olarak kullanımını değerlendirmek amacıyla soru formu ${ }^{2}$ hazırlanmıştır. Soru formu 3 bölümden oluşmaktadır. Soru formu Eskişehir Osmangazi Üniversitesi Etik Kurulu tarafından tez sürecinde onaylanmıştır.

- Birinci bölüm soruları "Frigya Kültür ve Termal Turizm Gelişim Bölgesi”nde yer alan Eskişehir'de mevcut termal tesislerinin genel özelliklerini ve kapasitelerini tanımlamak ve "Termal Turizm Kentleri Projesi" döneminde faaliyete giren tesislerin belirlenmesi amaçlamıştır.

- İkinci bölüm soruları bölgesel kalkınma sürecinde büyük önem arz eden çağdaş termal turizm kompleksleri ile Eskişehir termal tesislerinin benzerlik ve farklılıklarını belirlemek ve bu sayede mevcut politikaların çalışma kapsamına alınan tesisler üzerindeki etkisini açıklamayı amaçlamıştır.

- Üçüncü bölüm soruları tesis yöneticilerinin termal turizm bağlamında sorunları ve çözüm önerilerinin yanı sıra mevcut devlet politikaları hakkında farkındalıkları, bakış açıları ve hizmet standartlarının geliştirilmesi ile ilgili devlet politikalarından beklentilerini belirlemeyi amaçlamıştır.

\footnotetext{
${ }^{2}$ Soru formu T.C. Eskişehir Osmangazi Üniversitesi Sosyal ve Beşeri Bilimler Bilimsel Araştırma ve Yayın Etiği Kurulu'nun 23.05.2018 tarihli toplantısında incelenmiş ve uzmanlar tarafindan getirilen öneriler doğrultusunda düzeltmeler yapılarak uygulanmıştır.
} 
Çalışmada nitel araştırma yöntemi olarak araştırmacı tarafından tesis yöneticileriyle yüz yüze görüşme yöntemi uygulanmıştır. Nitel araştırma yöntemi genel kabul edilen görüşe göre nicel yönteme kıyasla uygulanması daha zor ve karmaşık bir süreç içerir ve daha az sayıda kişiden derin ve detaylı bilgi alabilmeyi amaçlar. Böylece nicel yöntemler ile elde edilemeyen ya da açıklanması güç olan veriler daha sağlıklı değerlendirilebilir (Patton, 2014: 14; Temizkan, 2005: 47). Tesisler ile yapılan görüşmeler yöneticilerin belirledikleri randevular paralelinde 24.05 .2018 ve 28.05.2018 tarihleri arasında gerçekleştirilmiştir. Görüşme sırasında yöneticilerin yanıtları araştırmacı tarafından yazılı olarak kaydedilmiştir.

\section{Bulgular ve Tartışma}

\subsection{Birinci Bölüm Bulguları ve Değerlendirilmesi}

Birinci bölüm soruları 5 adet sorudan oluşmaktadır ve bulgular Tablo 4'de gösterilmektedir.

Tablo 4: Birinci Bölüm Bulguları (2018)

\begin{tabular}{|l|c|c|c|c|}
\hline Sorular & A Tesisi & B Tesisi & C Tesisi & D Tesisi \\
\hline Bina Yaşı & 42 & 31 & 91 & 4 \\
\hline Kuruluş Tarihi & 1976 & 1993 & 2015 & 2017 \\
\hline Oda/Yatak Sayısı & $48 / 87$ & $35 / 54$ & $32 / 48$ & $164 / 350$ \\
\hline $\begin{array}{l}\text { Bedensel Engelli Oda } \\
\text { Sayısı }\end{array}$ & - & - & - & 4 \\
\hline Kadrolu Personel Sayısı & 42 & 14 & 19 & 140 \\
\hline
\end{tabular}

Eskişehir'in termal kaynak potansiyeli dikkate alındığı takdirde söz konusu belgelere sahip olan tesis sayısının yetersiz olduğu düşünülmektedir. $A, B, C$ ve $D$ tesislerinin bina yaşı ve kuruluş tarihleri incelendiğinde; $A$ ve $B$ tesislerinin hizmet süresi 20 yılın üzerindedir. Bu durum hizmet tecrübesi açısından oldukça önemlidir. Ancak söz konusu tesislerin bina yaşı uluslararası hizmet standartlarında modernizasyonu olumsuz etkilemektedir. Aynı durum bina yaşı 91 işletme yaşı 3 olan C tesisi içinde geçerli olabilmektedir. $C$ tesisinin modernizasyonu sağlanmış ancak söz konusu modernizasyon fiziksel kapasite yetersizliği nedeniyle termal turizm alanında hizmet verebilmek için değil standart konaklama hizmetlerine yöneliktir. D tesisinin ise bina yaşı 4 işletme yaşı 1 olup termal turizm kapsamında hizmet sunumuna en elverişli tesis olduğu düşünülmektedir.

A, B, C ve D tesislerinin oda sayısı sırasıyla $48,35,32$ ve 164 olup toplam oda sayısı 4 tanesi bedensel engelli bireylere yönelik olmakla birlikte 279 'dur. A, B, C ve D tesislerinin yatak sayısı ise sırasıyla $87,54,48$ ve 350 olup toplam yatak sayısı 539'dur. Eskişehir'in termal kaynak potansiyeli ve "Termal Turizm Kentleri Projesi" dikkate alındığı takdirde tesislerin mevcut kapasitelerinin termal turizm bağlamında yetersiz olduğu düşünülmektedir. Toplam oda sayısının içerisinde yalnızca $D$ tesisine ait 4 odanın bedensel engelli bireylere yönelik olması son derece sınırıdır.

A, B, C ve D tesislerinin personel sayısı sırasıyla 42, 14, 19 ve 140 olup tesislerin tamamında personeller kadrolu istihdam edilmektedir. Tesislerin tamamı geçici personel istihdam etmediklerini ifade etmişlerdir. Söz konusu oda ve yatak kapasitesine oranla istihdam edilen kişi sayısı karşılaştırıldığında personel kapasitesi 
oldukça yüksektir. Ancak söz konusu personellerin niteliği büyük önem taşımaktadır. Tesislerde nitelikli personel sayısının oldukça sınırlı olduğunu söylemek mümkündür. Tesislerin termal kür, Wellness ve SPA eğitimi almış personellere ihtiyacı olduğu düşünülmektedir. Öte yandan termal tesislerin hizmet çeşitliliğini artırabilmesi ve uluslararası standartlarda hizmet verebilmesi için bilhassa yönetici pozisyonunda çalışanların söz konusu alanlarda eğitimli olmaları yapılabilecek modernizasyon çalışmaları için oldukça önemlidir. Bunun yanı sıra A, B, C ve D tesisleri Kaplıcalar Yönetmeliği'nin 14. Maddesi gereği 1 uzman hekim ve 1 sağlık personeli istihdam etmekte olduklarını ifade etmişlerdir. Ancak, Kaplıcalar Yönetmeliği'nin ilgili maddesinde uzman hekimin birden fazla kaplıca tesisinde çalışabileceği belirtilmiştir. $\mathrm{Bu}$ bağlamda tedavi hizmeti vermesi amacıyla Sağlık Bakanlığı tarafından belgelendirilen tesislerde uzman hekimin tam zamanlı bulunmaması dikkat çekici nitelikte olup Kaplıcalar Yönetmeliği'nde bu anlamda da bir yapılandırılmaya gidilmesi gerektiği düşünülmektedir.

\section{2. İkinci Bölüm Bulguları ve Değerlendirilmesi}

İkinci bölüm soruları 5 sorudan oluşmaktadır ve bulgular Tablo 5'de gösterilmektedir.

Tablo 5: İkinci Bölüm Bulguları (2018)

\begin{tabular}{|l|c|c|c|c|}
\hline Sorular & A Tesisi & B Tesisi & C Tesisi & D Tesisi \\
\hline $\begin{array}{l}\text { Termal/Kaplıca Hizmeti } \\
\text { Veriler Ay/Aylar }\end{array}$ & $12 \mathrm{Ay}$ & $12 \mathrm{Ay}$ & $12 \mathrm{Ay}$ & 2015 Yılı \\
\hline $\begin{array}{l}\text { "Kaplıca Tesisi İşletme } \\
\text { İzni” Alınış Tarihi }\end{array}$ & 2012 Yılı & 2013 Yılı & 2017 Yılı & Masaj uygulamaları \\
\hline Wellness ve SPA hizmetleri & - & - & - & $\begin{array}{c}\text { Spor ve yoga alanları, } \\
\text { Yüzme havuzu } \\
\text { Okuma salonu }\end{array}$ \\
\hline Rekreasyon Faaliyetleri & - & - & - & - \\
\hline $\begin{array}{l}\text { Termal/Kaplıca Uygulanan } \\
\text { Hizmetlerinde Uymaler } \\
\text { Tedaviler }\end{array}$ & - & - & - & \\
\hline
\end{tabular}

A, B, C ve D tesislerinin tamamı yılın 12 ayı hizmet vermektedir. Bunun yanı sıra tesislerin "Kaplıca Tesisi İşletme İzni" belgesine "Termal Turizm Kentleri Projesi" nin orta dönemine karşılık gelen süreçte sahip olmaları olumludur. $A, B, C$ ve $D$ tesislerinin tamamında termal tedavi havuzları mevcuttur. Bu tesislerde ziyaretçiler termal havuzlardan geleneksel şekilde yararlanmaktadır. Termal kaynaklar tesisler tarafında bir ana ürün olarak arz edilmemekte genel olarak standart konaklama hizmeti vermektedirler. Bu tesislerde termal kür kapsamında faaliyet göstermediklerinden uluslararası hizmet standartlarına uygun değildirler.

$\mathrm{Bu}$ durum söz konusu tesislerde düşük geceleme sayısı ve doluluk oranına neden olmaktadır. A, B ve C tesislerinin Wellness ve SPA hizmetlerinin yanı sıra boş zaman geçirme amaçlı aktivite olanaklarının bulunmaması ve bu kapsamda ileriye dönük projelerinin olmadığını ifade etmeleri ne yazık ki çağdaş termal turizm komplekslerinden bu bağlamda da ayrıldıklarını göstermektedir. D tesisi ise gerek Wellness ve SPA hizmetleri kapsamında sunduğu masaj uygulamaları gerekse boş zaman geçirme amaçlı aktivite olanakları nedeniyle $A, B$ ve $C$ tesislerinden ayrılmakta olup çağdaş termal turizm komplekslerine yakınsamaktadır. 


\section{3. Üçüncü Bölüm Bulguları ve Değerlendirilmesi}

Üçüncü bölüm soruları 2 sorudan oluşmakta olup söz konusu sorular ve tesis yöneticilerinin verdikleri cevaplar aşağıda sıralanmaktadır.

Soru 1: "Termal turizm işletmeniz ile ilgili sorunlarınız ve çözüm önerileriniz nelerdir?"

- A ve $B$ tesislerinin termal turizm işletmesi olarak temel problemi termal kür uygulamaları ile ilgili hizmet vermek için binalarının eski ve fiziksel kapasitelerinin yetersiz oluşudur. Tesisler termal kür uygulamaları ile ilgili ziyaretçilerinin talebi olmasına rağmen modernizasyonlarını özel sebeplerin yanı sıra mevzuatlardan dolayı gerçekleştiremediklerini bu bağlamda da geleneksel günlük hamam hizmeti vermek zorunda kaldıklarını ifade etmişlerdir.

- C tesisi kendilerini termal turizm işletmesi olarak görmediklerinden bu kapsamda herhangi bir proje ve problemlerinin olmadığını ifade etmiştir.

- D tesisi ise, Eskişehir adına termal kür, Wellness ve SPA uygulamalarında yaşanan eksikliği bir bütün halinde önemsediklerini ve bu doğrultuda projeler geliştirdiklerini belirtmiştir. Projeler bağlamında en büyük sorunları olan fiziksel kapasitelerinin yetersizliğini aşmak için mevcut fizik tedavi merkezleri ile karşılıklı anlaşmalar yapmayı planladıklarını ifade etmiştir. Özellikle yabancı ziyaretçilerinin taleplerinin bu yönde olduğunu eklemiştir. Bunun yanı sıra söz konusu uygulamalar ile ilgili kalifiye personel eksikliğinin proje aşamasında dahi kendileri için oldukça sınırlayıcı bir problem olduğunu ifade etmiştir.

Soru 2: "Termal turizm işletmeniz ile ilgili devlet politikaları kapsamında beklentileriniz nelerdir?"

- A ve B tesislerinin ilk beklentisi eski ve yetersiz fiziksel kapasiteye sahip binalarında modernizasyonu sağlamak adına uzun vadeli geri ödeme opsiyonu olan finansal destektir. Söz konusu tesislerin bir diğer beklentisi ise "Kaplıcalar Yönetmeliği” ile ilgilidir. Bu bağlamda tesis doktorunun çalışma saatlerinin tam zamanlı çalışan sağlık personeli gibi düzenlenmesi gerektiği yönündedir.

- C tesisi termal turizm bağlamında beklenti içinde olmadıklarını ifade etmiştir.

- D tesisi ise, termal ve sağlık turizmine gerek yerel basında yer verilerek gerekse bu bağlamda organizasyonlar düzenlenerek termal kaynaklarımızın niteliklerinin ve koruyucu sağlık hizmetleri kapsamında öneminin yerel halka aktarılması gerektiğini ve termal turizm alanında başarı örneklerini vurgulayarak yatırımcıların dikkatlerinin çekilmesi gerektiğini ifade etmektedir. Eskişehir'in termal kaynaklarının yatırımcılara yeterli düzeyde tanıtımı için yerel yönetimlerce termal turizm adına alt birimler oluşturularak mevcut organizasyon eksikliğinin giderilebileceğini ve paydaşları bir araya getirebilecek etkinliklerin bu sayede düzenlenebileceğini eklemiştir.

$A$ ve $B$ tesisleri termal turizm alanına yapılan yatırımların hızlı bir geri dönüş sağlayacağını ifade etmektedirler. Bu nedenle tesislerde modernizasyonu sağlamak adına uzun vadeli geri ödemesi olan devlet desteği beklemektedirler. Ayrıca tabii oldukları mevzuat yapılandırılırsa termal kür hizmetini sağlayabileceklerini açıklamaktadırlar. D tesisi termal turizm hizmeti verebilmek için yol haritasını oluşturmuştur. Diğer termal kaynağa sahip tesisleri bu alanda hizmet vermeleri yönünde motive etmek amacıyla tanıtım ve bilgilendirme faaliyetlerinin düzenlenmesini devlet politikalarından beklemektedir. 


\section{Sonuç ve Öneriler}

Eskişehir'in termal kaynak potansiyeli dikkate alındığı takdirde Turizm İşletme Belgesi'ne sahip olan ve bunun yanı sıra Sağlık Bakanlığı tarafından "Kaplıca Tesisi İşletme İzni" verilmiş tesis sayısı ve kapasitelerinin düşük düzeyde olduğu ifade edilebilir. Bu durum bölgesel anlamda yeterli yatırımın gerçekleştirilmediğine işaret etmektedir. Tesisler hizmetlerini uluslararası standartlarda konaklama, termal kür uygulamaları, destek tedavi uygulamaları ve rekreasyon alanlarını içine alan bir yapıda sunmamaktadır. Uluslararası standartlarda termal tedavi hizmeti sağlamak için tesislerin fiziksel kapasitesi, tabii oldukları mevzuatlar modernizasyona engel olmakta ve tesisler standart konaklama işletmesi gibi hizmet vermektedir. Tesis bünyelerinde yer alan termal havuz ana ürün olarak değil sadece geleneksel kaplıca/hamam olarak kullanılmaktadır. Tesis yöneticileri uzun vadeli geri ödemesi olan devlet desteği ve mevzuatın yapılandırılmasını beklemektedir. Uluslararası termal turizm işletmeciliği hakkında yeterli düzeyde bilgi sahibi olmadıkları bu alanda eğitime intiyaç duydukları söylenebilir. Bölgenin gelişmesine istihdam açısından bakıldığında, tesis personelinin turizm ve bilhassa termal turizm alanında çalışabilecek nitelikte olmadıkları gözlemlenmiştir. Uzman hekim ve sağlık personeli tam zamanlı olarak istihdam edilmemektedir. Kaplıcalar Yönetmeliği'ne göre uzman hekimin birden fazla kaplıca tesisinde eş zamanlı olarak çalışabilmesi hizmetin verimliliğini olumsuz etkilemektedir.

Mevcut tesislerin kısa sürede katma değer yaratacak tedavi merkezlerine dönüştürülmesi için fiziksel yapı ve kapasitelerinde değişim sağlanmalıdır. Bu değişim için de öncelikle mevcut hukuki engellerin giderilerek yerel ve merkezi yönetimlerce tesislerin teşvik edilmesi gerektiği düşünülmektedir. Bölgede fizik tedavi merkezi olarak hizmet veren diğer tesisler ile anlaşma sağlanarak mevcut tesislerin dönüşümlerine hız kazandırılabilir. 'Konaklamalı Fizik Tedavi ve Rehabilitasyon Merkezleri Hakkında Yönetmelik' de söz konusu öngörüyü destekleyici nitelikte maddeler bulunmaktadır. Ayrıca söz konusu tesisler ile seyahat acentaları anlaşmalar yaparak Eskişehir Merkez Bölgesi'nde yer alan termal kaynakların bir destinasyon merkezi olarak tanıtımasını sağlayabilirler. Mevcut tesislerin çoğu ziyaretçilerin boş zamanlarını değerlendirebilecekleri hizmetler arz etmemektedir. Ancak tesislerin şehir merkezinde yer almaları ve Eskişehir'in rekreasyon alanları bakımından her geçen gün daha da zenginleşmesinin yanı sıra bölgenin sahip olduğu tarihi doku göz önüne alındığında tesislerin yabancı dil bilen turist rehberleri aracılığıyla ziyaretçilerinin boş zamanlarını geçirmeleri ile ilgili çevre bölgelere turlar düzenlenebilir. Eskişehir merkezinde yer alan termal kaynakların termal turizm adına rasyonel kullanımının sağlanması termal tedaviye elverişli olacak biçimde geceleme sayısını arttırarak, yeni uygulamalar ve yeni istihdam alanları yaratarak bölgesel kalkınmaya destek olacaktır.

Çalışma kapsamındaki tesisler Eskişehir'in şehir merkezinde olmasına karşın Eskişehir'in termal kaynak potansiyeli sadece şehir merkezi ile sınırlı değildir. Kızılinler ve Mihalgazi-Sakarılıca bölgeleri için hazırlanan plan ve projeleri hayata geçirebilmek amacıyla niçin yatırım yapılamadığı sorgulanması gereken bir durum olarak düşünülmektedir. Eskişehir'de termal kaynakların etkin bir şekilde kullanılmadığı ve atıl kaldığı söylenebilir. Bu bağlamda termal kaynaklar bölgenin kalkınmasında etkin değildir. Ayrıca “Termal Turizm Kentleri"nde belgeli tesisler ile yapılacak bu tür uygulamalı çalışmalar, termal kaynakların etkin kullanımında yol gösterici olacaktır.

\section{Kaynakça}

Aksu, C. ve Aktuğ, E. (2011). "Güney Ege Bölgesi Termal Turizm Araştırması", Güney Ege Kalkınma Ajansı, ss. 1-42. 
Aydın, D. (2014). Türkiye Sağlık Turizmi El Kitabı, (Çevirimiçi), http://www.ipsa.org.tr/upload/kitap/visitturkeyforhealthcare-pocket-book-tr.pdf (20.06. 2017).

Banger, G. (2002). Eskişehir'in Şifalı Sıcak Su Zenginliği, Eskişehir Ticaret Odası Araştırma Yayınları, No: 17, Eskişehir.

Başol, K. (1994). Doğal Kaynaklar Ekonomisi, Anadolu Matbaası, İzmir.

Başol, K., Durman, M. ve Çelik, M. Y. (2005). "Kalkınma Sürecinin Lokomotifi; Doğal Kaynaklar”, Muğla Üniversitesi Sosyal Bilimler Enstitüsü Dergisi, No: 14, ss. 6171.

Çeken, H. (2008). "Turizmin Bölgesel Kalkınmaya Etkisi Üzerine Teorik Bir İnceleme”, Afyon Kocatepe Üniversitesi, I.I.B.F. Dergisi, C: 10, No: 2, ss. 293-306.

Çeken, H. (2016). Turizm Ekonomisi, 2b., Detay Yayıncılık, Ankara.

Eskişehir III Kültür ve Turizm Müdürlüğü, (Çevirimiçi), http://www.eskisehirkulturturizm.gov.tr/TR,158580/sakariilica-kaplicalari.html (09.03. 2018).

Eskişehir İl Kültür ve Turizm Müdürlüğü, (Çevirimiçi), http://www.eskisehirkulturturizm.gov.tr/TR,158582/kizilinlerkaplicasi.html (11.03.2018).

Eskişehir Turizm Master Planı, 2011-2015. (2011). Anadolu Üniversitesi Yayınları, Eskişehir.

Gülel, F. E., Çağlar, A., Kangallı Uyar, S. G., Karadeniz, O. ve Yeşilyurt, M. E. (2017). "Türkiye'de İllere Göre İnsani Gelişme Endeksi", Pamukkale Üniversitesi Sosyal Bilimler Enstitüsü Dergisi, No: 27, ss. 208-216.

Kaplıcalar Yönetmeliği, (Çevirimiçi), http://cevresagligi.thsk.saglik.gov.tr/2013-08-2813-18-43/mevzuat/972-kapl\%C4\%B1calar-y\%C3\%B6netmeli\%C4\%9Fi.html (09.05. 2017).

Karagülle, Z. (Çevirimiçi), http://www.termalspasaglik.com/kaplica-tibbinda-tanimlar/ (05.05.2017).

Kaya, A. A. (2009). "Sürdürülebilir Kalkınma ve Yoksulluk", Editör: Erol Kutlu, Iktisadi Kalkınma ve Büyüme, Anadolu Üniversitesi Yayını, Eskişehir, ss. 215-242.

Kültür ve Turizm Bakanlığı, (Çevirimiçi), http://yigm.kulturturizm.gov.tr/TR,11475/geneltanimlar.html (02.05.2017).

Kültür ve Turizm Bakanlığı, (Çevirimiçi), http://yigm.kulturturizm.gov.tr/TR,9859/tesisistatistikleri.html (25.02.2018).

Kültür ve Turizm $\quad$ Bakanlığı, $\quad$ (Çevirimiçi), http://yigm.kulturturizm.gov.tr/TR,9857/isletme-belgeli-tesisler.html (01.03.2018).

Kültür ve Turizm Bakanlığı, (Çevirimiçi), http://yigm.kulturturizm.gov.tr/TR,9669/ktkgbve-turizm-merkezleri.html (07.05. 2018).

Özbek, T. (1990). "Termal Turizmin Önemi ve Değerlendirilmesi Eskişehir'in Termal Turizmdeki Yeri”, Eskişehir Kaplıca Turizmi Semineri 3 Şubat 1990, Güven Tanyeri (1999), İşcan Güzel Sanatlar Ofisi, Eskişehir.

Özbek, T. (2015). “Jeotermal Kaynakların Sağlık ve Termal Turizmde Etkin Kullanımı”, Editör: Mustafa Altındiş, Termal Turizm, Nobel Yayınları, Ankara, ss. 57-78.

Özdemir, Ş. (2015). "Türkiye'nin Termal Sağlık Turizmi Potansiyeli”, Editör: Mustafa Altındiş, Termal Turizm, Nobel Yayınları, Ankara, ss. 1-12.

Özdipçiner, N. S. (2018). Termal Turizm, Detay Yayıncılık, Ankara.

Patton, M. Q. (2014). Nitel Araştırma ve Değerlendirme Yöntemleri (3.Baskıdan Çeviri), Çeviri Editörleri: Mesut Bütün, Selçuk Beşir Demir. Pegem Akademi, Ankara.

Sağlık

Bakanlığı,

(Çevirimiçi), http://cevresagligi.thsk.saglik.gov.tr/dosya/Su/Tesis listesi 2016 Haziran.pdf (20.07.2017).

Şimşek, M. (2003). Şifalı Sulara Yolculuk Kaplıcalar-lçmeler, 2b., İnkilap Kitabevi, İstanbul. 
Temizkan, S. P. (2005). "Turistlerin Alışveriş Davranışı: Kapadokya Örneği”, Mustafa Kemal Üniversitesi Sosyal Bilimler Enstitüsü, Yüksek Lisans Tezi.

Tengilimoğlu, D. ve Karakoç, G. (2013). "Termal Turizm ve Spa Turizmi”, Editör: Dilaver Tengilimoğlu, Sağlık Turizmi, Siyasal Kitabevi, Ankara, ss. 71-97.

Tokmak, C. (2015). "Termal Turizm”, Editör: Saadet Pınar Temizkan, Sağlık Turizmi, Detay Yayıncılık, Ankara, ss. 37-73.

Tontuş, H. Ö. (2015). Tüm Yönleriyle Sağlık Turizmi / Sağlık Turizmi Nedir?, SATÜRK, (Çevirimiçi), http://www.saturk.gov.tr/images/pdf/tyst/02.pdf (20.12. 2016).

Tontuş, H. Ö. (2015). Tüm Yönleriyle Sağlık Turizmi / Türkiye'de Termal Sağlık Turizmi, SATÜRK, (Çevirimiçi), http://www.saturk.gov.tr/images/pdf/tyst/07.pdf (05.03.2017).

UNWTO, (2017). "Tourism Highlights", (Çevirimiçi), https://www.eunwto.org/doi/pdf/10.18111/9789284419029 (03.05.2018).

Yardan, E. D., Dikmetaş, H., Us, N. C. ve Yabana, B. (2014). "Türkiye ve Dünya'da Sağlık Turizmi", Sağlıkta Performans ve Kalite Dergisi, No: 8, ss. 27-42.

Yeung, O. ve Johnston, K. (2017). Global Wellness Economy Monitor, Global Wellness Institute,

Miami. 


\begin{tabular}{|c|c|c|c|c|c|c|c|c|c|c|c|c|c|c|c|c|c|c|c|}
\hline \multirow[t]{2}{*}{ Türü } & \multirow[t]{2}{*}{ Sinıfı } & \multicolumn{3}{|c|}{ TYB (2007) } & \multicolumn{3}{|c|}{ тїв (2007) } & \multicolumn{3}{|c|}{ TYB (2012) } & \multicolumn{3}{|c|}{ TíB (2012) } & \multicolumn{3}{|c|}{ TYB (2017) } & \multicolumn{3}{|c|}{ TíB (2017) } \\
\hline & & $\begin{array}{l}\text { Tesis } \\
\text { Sayısı }\end{array}$ & $\begin{array}{c}\text { Oda } \\
\text { Sayısı }\end{array}$ & $\begin{array}{l}\text { Yatak } \\
\text { Sayısı }\end{array}$ & $\begin{array}{c}\text { Tesis } \\
\text { Sayıs } \\
1\end{array}$ & $\begin{array}{c}\text { Oda } \\
\text { Sayısı }\end{array}$ & $\begin{array}{c}\text { Yatak } \\
\text { Sayıs } \\
1\end{array}$ & $\begin{array}{c}\text { Tesis } \\
\text { Sayis } \\
1\end{array}$ & $\begin{array}{c}\text { Oda } \\
\text { Sayıs } \\
1\end{array}$ & $\begin{array}{l}\text { Yatak } \\
\text { Sayısı }\end{array}$ & $\begin{array}{c}\text { Tesis } \\
\text { Sayis } \\
1\end{array}$ & $\begin{array}{c}\text { Oda } \\
\text { Sayısı }\end{array}$ & $\begin{array}{c}\text { Yatak } \\
\text { Sayıs } \\
1\end{array}$ & $\begin{array}{l}\text { Tesis } \\
\text { Sayısı }\end{array}$ & $\begin{array}{c}\text { Oda } \\
\text { Sayis } \\
1\end{array}$ & \begin{tabular}{|l} 
Yatak \\
Sayısı
\end{tabular} & $\begin{array}{c}\text { Tesis } \\
\text { SayIS } \\
1\end{array}$ & $\begin{array}{c}\text { Oda } \\
\text { Sayısı }\end{array}$ & $\begin{array}{c}\text { Yatak } \\
\text { Sayıs } \\
1\end{array}$ \\
\hline \multirow[t]{4}{*}{$\begin{array}{c}\text { Termal } \\
\text { Otel }\end{array}$} & 5 Yıldızlı & 6 & 1587 & 4348 & 3 & 748 & 1692 & 10 & 2444 & 5602 & 21 & 5246 & $\begin{array}{c}1134 \\
0\end{array}$ & 16 & 6717 & 14667 & 36 & 9036 & $\begin{array}{c}1923 \\
9\end{array}$ \\
\hline & 4 Yıldızlı & 1 & 400 & 1593 & 1 & 150 & 303 & 9 & 1162 & 2838 & 14 & 1916 & 4055 & 11 & 1281 & 2708 & 27 & 2697 & 5622 \\
\hline & 3 Yıldızlı & 3 & 216 & 458 & 7 & 350 & 758 & 5 & 291 & 606 & 15 & 852 & 1753 & 5 & 473 & 1147 & 19 & 1164 & 2432 \\
\hline & 2 Yıldızlı & - & - & - & 1 & 21 & 42 & - & - & - & 1 & 34 & 68 & - & - & - & - & - & - \\
\hline TOPLAM & & 10 & 2203 & 6399 & 12 & 1269 & 2795 & 24 & 3897 & 9046 & 51 & 8048 & $\begin{array}{c}1721 \\
6\end{array}$ & 32 & 8471 & 18522 & 82 & 12897 & $\begin{array}{c}2729 \\
3\end{array}$ \\
\hline \multirow[t]{2}{*}{$\begin{array}{c}\text { Termal } \\
\text { Tatil } \\
\text { Köyleri }\end{array}$} & 5 Yıldızlı & & - & - & - & - & - & 1 & 129 & 310 & - & - & - & - & - & 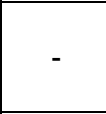 & - & - & - \\
\hline & 4 Yıldızlı & - & - & - & - & - & - & 1 & 200 & 638 & - & - & - & 1 & 99 & 198 & - & - & - \\
\hline TOPLAM & & - & - & - & - & - & - & 2 & 329 & 948 & - & - & - & 1 & 99 & 198 & - & - & - \\
\hline $\begin{array}{c}\text { Termal } \\
\text { Müstakil } \\
\text { Apart Otel }\end{array}$ & & - & - & - & & 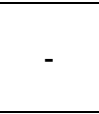 & - & & - & - & - & - & - & - & & - & 2 & 81 & 171 \\
\hline
\end{tabular}

\section{Ek 1: Turizm Belgeli Termal Konaklama Tesislerinin Sayısı}

Kaynak: Kültür ve Turizm Bakanlı̆̆ı 25.02.2018 